\title{
Enhancing organic waste decomposition with addition of phosphorus and calcium through different sources
}

\author{
Frank Oshioname Unuofin ${ }^{1} \cdot$ Msimelelo Siswana ${ }^{1}$
}

Received: 3 July 2017 / Accepted: 17 December 2018 / Published online: 29 December 2018

(c) The Author(s) 2018

\begin{abstract}
Purpose This study assessed the constituent element in rock phosphate (RP) that is responsible for enhancing quick decomposition of cow dung-waste paper mixtures during vermicomposting.

Method Feedstock weighing $5 \mathrm{~kg}$ was achieved by mixing $2.16 \mathrm{~kg}$ shredded waste paper together with $2.84 \mathrm{~kg}$ cow dung sprinkled with water and then enriched with (1\% P) as RP from triple superphosphate (TSP), phosphoric acid (PHA) and $\mathrm{Ca}$ in the form of $\mathrm{CaCl}_{2}$ at the level supplied by RP. After mixing, they were loaded into vermireactors and inoculated with matured earthworms at a stocking density of $12.5 \mathrm{~g}$ worms $/ \mathrm{kg}$ feed for the entire 56 days. The decomposition of the mixtures was then monitored by measuring maturity parameters, a germination test for phyto-toxicity and morphological properties was assessed using scanning electron microscopy (SEM).

Result Results revealed that rapid decomposition of waste was recorded where TSP was applied than RP whereas Ca-source had the least effect. A C:N ratio of 12 was achieved within 28 days where TSP was added, while RP, PHA and $\mathrm{CaCl}_{2}$ needed 42,56 and more than 56 days, respectively.

Conclusion It was evidently revealed from the results that $\mathrm{P}$ was basically the cause of the improved decomposition of the waste mixtures. To achieve quicker and well-humified enriched vermicompost with a C:N ratio of 10 within 20 days of vermicomposting, add water-soluble P sources.
\end{abstract}

Keywords Vermidegradation $\cdot$ Phosphorus $\cdot$ Enhancement $\cdot$ Organic waste mixtures $\cdot$ Humification

\section{Introduction}

Integration of rock phosphate (RP) and P-solubilizing microorganisms into several wastes aimed at nutrient enrichment during vermicomposting have been extensively studied (Mupondi et al. 2010; Biswas and Narayanasamy, 2006; Edwards et al. 2010; Masciandaro et al. 1997; Senesi et al. 1992; Garg and Kaushik 2005; Kaushik and Garg 2004). This is because most waste materials used for composting or vermicomposting (e.g., agricultural wastes, dairy wastes, paper waste, industrial wastes and household wastes), in their natural form, have little nutrient contents of phosphorus and nitrogen among the vital key macro-nutrients required for plant maximum development (Mupondi et al.

Frank Oshioname Unuofin

funmifrank2009@gmail.com

1 Department of Applied Science, Walter Sisulu University, 19 Manchester Road, Chislehurst, P.O. Box 19712,

East London, South Africa
2010, Biswas and Narayanasamy 2006, Edwards et al. 2010). Besides, RP according to Premono et al. (1996); Kumar and Narula (1999) cannot be applied directly into the soil because of its low dissolution rate, reactivity and high soil $\mathrm{pH}$.

In the light of this, Mupondi (2010) during a vermicomposting study mixed RP with shredded waste paper and dairy manure mixtures at proportion greater than $2 \% \mathrm{P}$ and stated a successfully better decomposition and humification of waste mixture as well as enhanced $P$ availability through increase in the labile pools and less labile pools of P. This was attributed to a collective effect of decomposition of organic matter together with the dissolution of the applied RP. Mupondi (2010) further detected that, added RP improved the overall $\mathrm{N}$ content of the vermicomposting mixture with time and attributed it to the absorption influence produced by weight decrease of the organic material resulting from organic matter decomposition and loss of $\mathrm{C}$ as carbon dioxide, joined with improved nitrogen mineralization in the substrate as 
reported by (Atiyeh et al. 2000) when they included $>4 \%$ $\mathrm{RP}$ into kitchen waste during composting.

However, according to Singh and Amberger (1990), when $\mathrm{RP}$ is mixed with organic solid wastes, it both increased the $P$ content and humification of the vermicompost. In another study, (Mishra 1992) got an exceedingly humus-like manure when they composted vegetable wastes with 25\% Mussoorie RP.

Unuofin et al. (2016) explored the effectiveness of adding RP at rates less than $2 \% \mathrm{P}$ to cow dung-waste paper mixtures. The result revealed that, an improved decomposition and humification of the mixtures could be realized even at $0.5 \% \mathrm{P}$ rate of RP application, even though faster decomposition as well as maturation was achieved at $1 \% \mathrm{P}$. Although, $1 \% \mathrm{P}$ application rate of rock phosphate is what is vital to produce mature vermicompost; however, application greater than $1 \% \mathrm{P}$ was desirable for vermicompost-enriched P fertilizer.

Based on the elemental nutrient composition of RP, calcium and phosphorous are the dominant elements in most rock phosphates. It was, therefore, hypothesized that since $\mathrm{Ca}$ and $\mathrm{P}$ were the dominant nutrient elements in RP, they could be responsible for the observed improved decomposition of the mixtures. Hence, it was examined by comparing disintegration of ( $1 \% \mathrm{P})$ of $\mathrm{RP}$, triple superphosphate (TSP), and phosphoric acid (PHA) with $\mathrm{Ca}$ in the form of $\mathrm{CaCl}_{2}$-enriched waste mixtures.

Therefore, the main objective of this study was to determine if $\mathrm{P}$ or $\mathrm{Ca}$ in the rock phosphate cause the observed enhanced decomposition of the waste mixtures during vermicomposting. A secondary objective was to determine the extractability of $\mathrm{P}$ in vermicomposts treated with the different $\mathrm{P}$ sources.

\section{Materials and methods}

\section{Site description, wastes and earthworms utilized}

The experiment was done at the University of Fort Hare, Alice (32 46'S and $2650^{\prime} \mathrm{E}$ ) under a room temperature of $25{ }^{\circ} \mathrm{C}$ in a closed shaded yard. Waste paper used was sourced from both the faculties and Xerox, the University printing press. Phalaborwa in Mpumalanga Province in South Africa supplied phosphate rock. The University local wormery supplied Eisenia fetida earthworms. Manure was collected from the Dairy farm in Keiskammahoek. Soluble P fertilizer (Triple super phosphate) was obtained from a company that sells fertilizer in East London. Merck, a chemicals company in Pretoria, South Africa supplied phosphoric acid and calcium chloride.

\section{Experimental procedure}

Worm containers gauging $0.50 \mathrm{~m} \times 0.40 \mathrm{~m} \times 0.30 \mathrm{~m}$ (length $\times$ width $\times$ depth) were used. This offered $0.2 \mathrm{~m}^{2}$ of exposed top surface. Matured worms were introduced at a mass of $12.5 \mathrm{~g}$ worms $/ \mathrm{kg}$ feed (Unuofin and Mnkeni 2014). A C:N ratio of 30 was achieved by adding $2.16 \mathrm{~kg}$ shredded paper with $2.84 \mathrm{~kg}$ cow dung to get $5 \mathrm{~kg}$ (dry basis) feedstock that was placed in vermicomposting boxes to accommodate earthworms need for the whole 56 days. Experimental treatments had three replications in a completely randomized design. Boxes were kept at $80 \%$ moisture content by sprinkling water when necessary throughout the vermicomposting period (Reinecke and Venter 1987).

\section{Experimental treatments}

Rock phosphate (RP), Triple superphosphate (TSP), Phosphoric acid (PHA) and calcium chloride $\left(\mathrm{CaCl}_{2}\right)$ were the treatments used. The $\mathrm{P}$-source treatments were inoculated into the waste mixtures at $1 \%, \mathrm{P}$ since this gave the ideal rate of RP application that brought about speediest decomposition of the waste mixtures (Unuofin et al. 2016). Calcium chloride was also applied to the mixtures at the level of $\mathrm{Ca}$ supplied by RP when applied at $1 \%$ P. A control (with earthworm yet no $\mathrm{P}$ sources) was included. RP, TSP and PHA were mixed each at a rate of $1 \% \mathrm{P}$ but $\mathrm{CaCl}_{2}$ was mixed at the level of Ca provided by RP to every $5 \mathrm{~kg}$ (dry matter basis). All treated mixtures were vermicomposted in worm boxes having $0.2 \mathrm{~m}^{2}$ uncovered top surfaces. Mixtures were inoculated independently with various treatments, and mixed with developed worms at a known stocking density.

\section{Physico-chemical analyses}

The samples were analyzed for physiochemical characteristics of the organic mixtures using international standard laboratory methods and procedures for total carbon $(\mathrm{C})$, total nitrogen $(\mathrm{N}), \mathrm{pH}$, electrical conductivity (EC), volatile solids (VS), and ash content extractable phosphorus $\mathrm{P}$, and humic substances. $\mathrm{pH}$ and $\mathrm{EC}$ were determined in a 1:2.5 OM:water mixture). The colloidal mixtures were left to stand for an hour after continuous shaking by a mechanical shaker at $230 \mathrm{rpm}$ for $30 \mathrm{~min}$ preceding $\mathrm{pH}$ and EC measurements. Whilst, sample weight loss (previously oven-dried at $105^{\circ} \mathrm{C}$ ) upon ashing at $550{ }^{\circ} \mathrm{C}$ for $4 \mathrm{~h}$ in a muffle furnace was used to determine volatile solids according to (Ndegwa et al. 2000). Truspec CN Carbon/Nitrogen analyser (LECO Corporation 2003) was used to measure Total $\mathrm{N}$ and $\mathrm{C}$ of the samples. Bray P extractant was used to assess the extractable P of organic wastes. A continuous flow analyzer (San $2++$ Skalar CFA, Skalar Analytical B.V. The Netherlands) 
was used to estimate the orthophosphate in the extracts through the ammonium molybdate-antimony potassium tartrate-ascorbic acid method.

\section{Humic substances determination}

Del Carmen et al. (2006) method for humic acid extraction procedure was used. Firstly, $0.1 \mathrm{M} \mathrm{NaOH}(1: 20 \mathrm{w} / \mathrm{v}$ ratio) was used to treat the samples, and thereafter shaken $4 \mathrm{~h}$ on a flat agitator. Resultant colloidal mixture was swirled at $8000 \mathrm{rpm}$ or $8000 \times \mathrm{g}$ for $15 \mathrm{~min}$. After that, the clear solution was divided into two halves. Walkley and Black (1934) fast titration method was used to analyze the first half for total extractable carbon fraction $\left(C_{\mathrm{EX}}\right)$ as defined by (Anderson and Ingram 1996); whereas, the remaining half was attuned to a pH 2 by adding concentrated $\mathrm{H}_{2} \mathrm{SO}_{4}$ and then left to coagulate for $24 \mathrm{~h}$ at $4{ }^{\circ} \mathrm{C}$. The resulting precipitates constituted the humic acid-like carbon $\left(C_{\mathrm{HA}}\right)$ while portion that remained in solution constituted the fulvic acid-like carbon $\left(C_{\mathrm{FA}}\right)$. The $\mathrm{CHA}$ was calculated by subtracting the $C_{\mathrm{FA}}$ from the $C_{\mathrm{EX}}$. The humification ratio (HR) was calculated as $\mathrm{HR}=\left(C_{\mathrm{EX}} / C\right) \times 100$ and humification index $(\mathrm{HI})$ was calculated as $\mathrm{HI}=\left(C_{\mathrm{HA}} / C\right) \times 100$. PI was calculated as the ratio of $C_{\mathrm{HA}}$ to $C_{\mathrm{FA}}$ (Mupondi 2010).

\section{Phytotoxicity study}

Phytotoxicity was assessed through a seed germination test. Aqueous extracts were prepared from the different vermicomposts with distilled water $(1: 10 \mathrm{w} / \mathrm{v})$ (Unuofin and Mnkeni 2014). The seed germination bioassay for tomato (Lycopersicon esculentum), radish (Raphanus sativus) and carrot (Daucus carota) was assessed by Tim and Tiquia (Tam and Tiquia 1998) in which two portions of Whatman ${ }^{\circledR}$ filter paper were set inside a cleaned petri dish and wetted with the vermicompost extracts. Ten seeds of each yield species were set on the filter paper and keep warm for 5 days in the dark. A control was included for each yield species in which the filter papers were wetted with distilled water. Germination index (GI), relative seed germination (RSG) and relative root lengthening (RRE) were determined as follows:

$$
\begin{aligned}
& \text { RSG }(\%) \\
& =\frac{\text { Number of seeds germinated in the sample extract } \times 100}{\text { Number of seeds germinated in the control }} . \\
& \text { RRE }(\%)=\frac{\text { Mean root elongation in the sample extract } \times 100}{\text { Mean root elongation in the control }} . \\
& \text { GI }(\%)=\frac{(\% \text { germination }) \times(\% \text { root elongation })}{100} .
\end{aligned}
$$

Table 1 Selected chemical properties of wastes used in the study

\begin{tabular}{lrr}
\hline Chemical property & \multicolumn{2}{c}{ Raw material } \\
\cline { 2 - 3 } & \multicolumn{1}{c}{ Cow dung } & Waste paper \\
\hline $\mathrm{pH}$ & $7.8 \pm 0.001$ & $8.2 \pm 0.001$ \\
$\mathrm{EC}(\mathrm{mS} / \mathrm{m})$ & $440 \pm 0.002$ & $0.18 \pm 0.001$ \\
Total N $(\mathrm{g} / \mathrm{kg})$ & $23 \pm 0.002$ & $3 \pm 0.002$ \\
Total C $(\mathrm{g} / \mathrm{kg})$ & $321 \pm 0.002$ & $370 \pm 0.001$ \\
C:N & $13.2 \pm 0.002$ & $205 \pm 0.001$ \\
Total P $(\mathrm{g} / \mathrm{kg})$ & $2.8 \pm 0.001$ & $0.5 \pm 0.001$ \\
Ash $(\mathrm{g} / \mathrm{kg})$ & $379 \pm 0.001$ & $178 \pm 0.001$ \\
$\mathrm{C}: \mathrm{P}$ & $110 \pm 0.001$ & $740 \pm 0.001$ \\
\hline
\end{tabular}

\section{Determination of the morphology of the vermicompost}

Scanning electron microscopy (SEM) model JOEL (JSM$6390 \mathrm{LV}$, Japan) was used to take samples imagery. Concisely, the trials were desiccated and pulverised to pass through a $2 \mathrm{~mm}$ mesh. A small representative percentage of the trials was smeared with gold and mounted on SEM. Trials were then imaged by scanning them with a high-energy beam of electrons in a raster scan pattern.

\section{Statistical analysis}

Result shown here are the means of three replicate $(n=3)$ which were subjected to repeated measure examination of change (ANOVAR). Fisher's protected least significant difference (LSD) test at $p \leq 0.05$ was utilized to decide mean separation. The results were analyzed using JMP ${ }^{\circledR}$ version 10.0 .

\section{Results and discussion}

\section{Initial physical and chemical properties of waste paper and cow dung}

Table 1 shows selected characteristics of mixtures used. Carbon content was low and nitrogen content was high in cow manure than in the waste paper. The same trend was observed for total $\mathrm{P}$; as a result, cow dung had narrower $\mathrm{C}: \mathrm{N}$ and $\mathrm{C}: \mathrm{P}$ ratios than waste paper. The $\mathrm{C}: \mathrm{N}$ ratio of cow dung and paper waste is found to be very narrow and very wide, respectively, because such ratio is necessary so that resident or inoculated microflora can multiply by producing extracellular hydrolytic enzyme. Most of the time, final $\mathrm{C}: \mathrm{N}$ ratio of compost depends upon initial $\mathrm{C}: \mathrm{N}$ ratio of the substrate. Interestingly, $\mathrm{C}: \mathrm{N}$ ratio of bacterial cell is also approximately 10:1. Cow manure had high EC and ash content compared to waste paper. The higher EC values in cow 


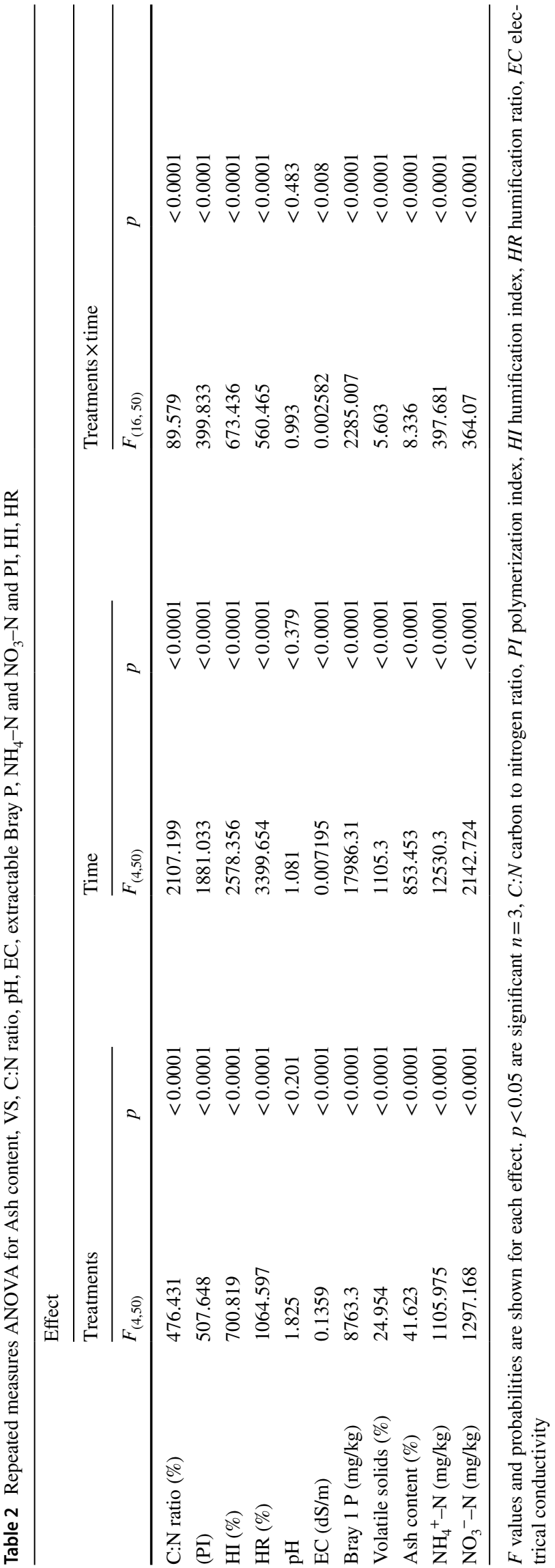

dung could be due to the release of salts from the manure with the passage of time. The $\mathrm{pH}$ of both material used for the experiment was alkaline; however, higher $\mathrm{pH}$ was recorded in waste paper.

\section{Treatment effects on selected compost stabilization and maturity parameters}

Table 2 shows the summary of the interaction amongst treatments and time during decomposition of the mixtures. Results indicated that there was pronounced substantial interaction between treatments and time.

\section{Effect of $\mathrm{P}$ and $\mathrm{Ca}$ bearing sources on the percentage Ash and VS}

Incorporating $\mathrm{P}$ and $\mathrm{Ca}$ sources into the mixtures significantly decreased the waste mixture volatile solids and cause a corresponding increase in percent ash of the resultant product; however, this effect was time dependent as shown by a significant treatments $\times$ time interaction (Table 2). In all treatments, percent ash increased with time, even though, there were variations in the magnitude among the different treatments (Fig. 1a). Absolute control yielded the lowest values, while the highest values were observed where phosphoric acid (PHA) was added. Generally, the water-soluble $\mathrm{P}$ sources resulted in higher percent ash values than the RP, $\mathrm{CaCl}_{2}$ and control treatments. Gupta et al. (2007); Khwairakpam and Bhargava (2009) reported that during vermicomposting, the concentration of ash increases which proposes that vermicomposting hastens the degree of mineralization and also cuts the amount of water-soluble chemical, which causes likely environmental contamination.

Volatile solids which varied between 71 and $78 \%$ in the mixtures, declined amongst initial and latter sampling dates all over the treatments (Fig. 1b). At days 14 and 28, except for PHA-treated waste, reduction in VS values of $\mathrm{CaCl}_{2}$-treated mixtures was not markedly different from the control; whereas, TSP- and RP-treated vermicomposts follow same pattern with a sudden drop between days 42 and 56 , respectively. The highest reduction of $50 \%$ in VS at day 56 corresponded to PHA-treated product, while the smallest percent ash increase of (35\%) occurred in control. Reduction in volatile solids content during vermicomposting of the waste mixtures could be as a result of the disintegration process by microbial activity and loss of carbon in the form of $\mathrm{CO}_{2}$ (Khwairakpam and Bhargava 2009; Singh and Kalamdhad 2013b). Utilization of carbon by microorganism as a primary energy source for their growth during the vermicomposting process might also cause the reduction of volatile solids (Khwairakpam and Bhargava 2009; Levanon and Pluda 2002). Singh and Kalamdhad (2013a) revealed that OM decreased with the amount of cattle manure inclusion 
Fig. 1 Effect of P and Ca bearing sources on the percentage ash and VS

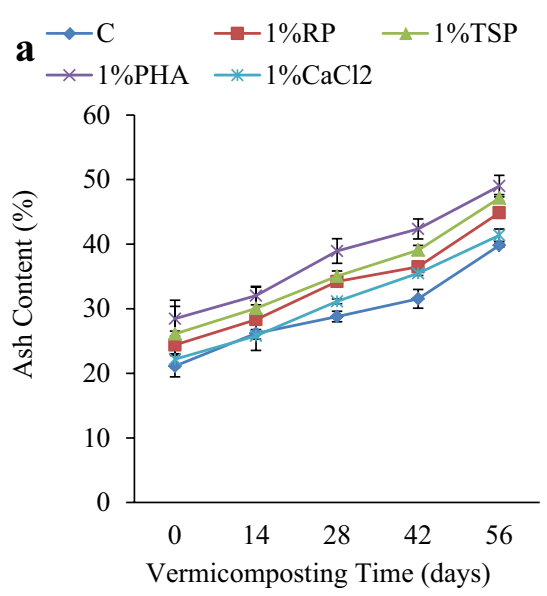

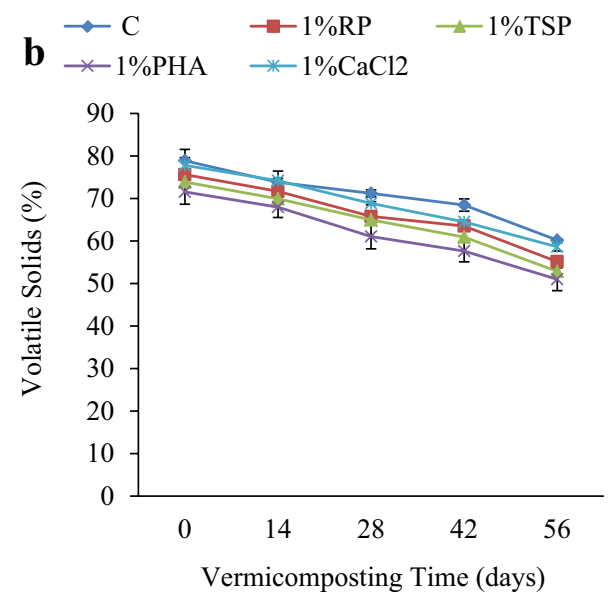

when water hyacinth was subjected to composting. Nevertheless, decrease of organic matter in this study was not subjected to the quantity of waste mixtures but may be because of the presence of easily available food for earthworms.

\section{Effect of $\mathrm{P}$ and $\mathrm{Ca}$ sources on $\mathrm{pH}$ and $\mathrm{EC}$}

At the beginning of the experiment, vermicomposts $\mathrm{pH}$ values ranged between 5.3 and 10.2 (Fig. 2a). The lowest $\mathrm{pH}$ was recorded where PHA was applied and the highest where $\mathrm{CaCl}_{2}$ was added. However, this effect varied with time as shown by the significant interaction between applied treatments and time (Table 2). While most of the treatments showed a significant $\mathrm{pH}$ decrease (RP, PHA, and $\mathrm{CaCl}_{2}$ ), others (control and TSP) showed no differences over time. The trends in which $\mathrm{pH}$ increased during vermicomposting corroborated the work of (Tripathi and Bhardwaj 2004 and Loh et al. 2005) who attributed it to higher fossilization of carbon-based substance as well as (Fares et al. 2005), who associated it with advanced ingestion of organic acids and rise in inorganic constituents of waste by earthworms activity. However, this present study contradicted the works of (Haimi and Huhta 1987; Ndegwa et al. 2000; Suthar and Singh 2008) in which they observed lower $\mathrm{pH}$ values and attributed it to the mineralization of nitrogen and phosphorus into nitrite, nitrates and orthophosphorus as well as the production of $\mathrm{CO}_{2}$ and organic acids through microbial decomposition.

Electrical Conductivity which varied from 4.1 highest to $3.8 \mathrm{dS} / \mathrm{m}$, increased and decreased over all the treatments between initial and last sampling date from 3.5 to $2.4 \mathrm{dS} / \mathrm{m}$ with the highest values of $\mathrm{EC}$ recorded where $\mathrm{CaCl}_{2}$ was applied (Fig. 2b). Two treatments, RP and control shadowed self-same patterns, with abrupt drop between days 42 and 56 (Fig. 2b). However, PHA-treated vermicompost followed a different trend, with lowest EC of $2.8 \mathrm{dS} / \mathrm{m}$ at day 14 but gradually increased beyond others except $\mathrm{CaCl}_{2}$-treated vermicompost at day 28 and thereafter followed similar pattern with RP and control, while TSP-treated vermicompost had the lowest EC values of $2.6 \mathrm{dS} / \mathrm{m}$ after day 14 and remained steadily low up till day 56 (Fig. 2b).
Fig. 2 Effect of $\mathrm{P}$ and $\mathrm{Ca}$ sources on $\mathrm{pH}$ and $\mathrm{EC}$

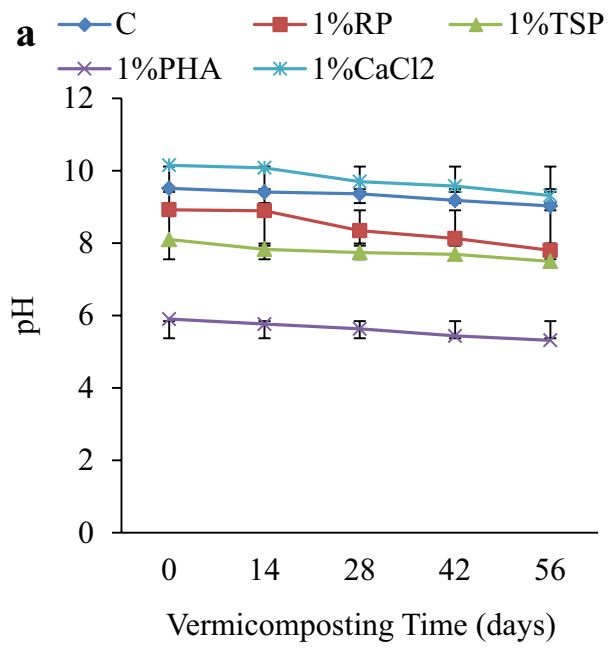

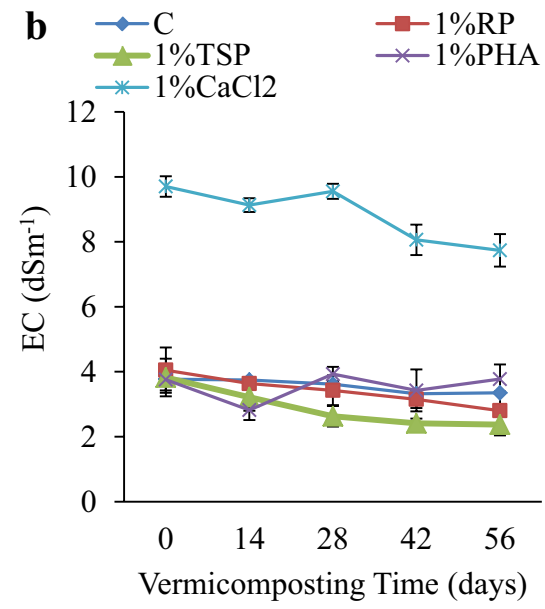


Electrical conductivity as reported by different scientists either increased or decreased during vermicomposting process, some workers reported decrease in electrical conductivity (Garg et al. 2006; Singh et al. 2009) and while others an increase in electrical conductivity (Hait and Tare 2011). The decrease has been attributed to a decrease in ions after forming a complex whereas the increase has been attributed to the degradation of organic matter to release cations and release of different mineral salts in available forms such as phosphate, ammonium, and potassium.

\section{Effect of $\mathrm{P}$ and $\mathrm{Ca}$ source on the $\mathrm{C}: \mathrm{N}$ ratio}

Added P source and Ca source had significant effects in reducing the $\mathrm{C}: \mathrm{N}$ ratio of vermicompost, as the effect differed significantly amongst treatments $\times$ time (Table 1 ). The $\mathrm{C}: \mathrm{N}$ ratio declined meaningfully with time, respectively, at supplementary P-nutrient source; however, there were

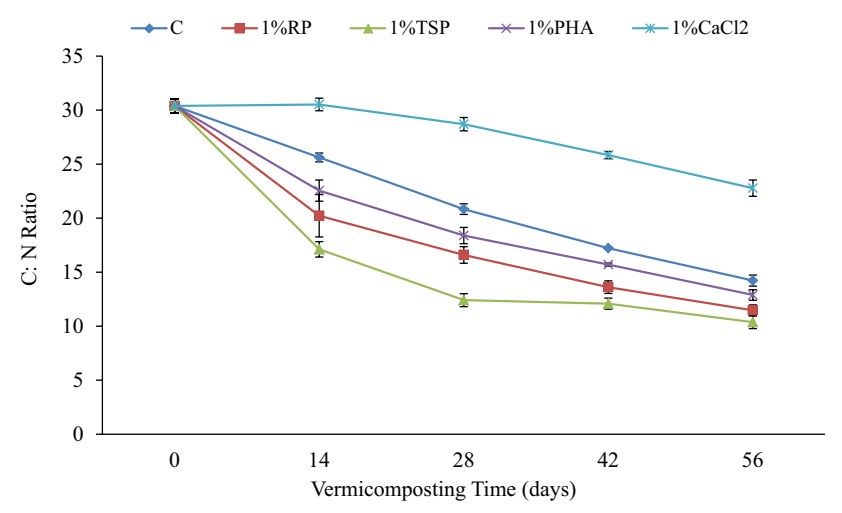

Fig. 3 Effect of $\mathrm{P}$ and $\mathrm{Ca}$ source on the $\mathrm{C}: \mathrm{N}$ ratio obvious differences between different P-source treatments up to 28 days, beyond which differences were minimal except for $\mathrm{CaCl}_{2}$-treated waste mixtures that spread wider apart (Fig. 3). The highest decline in C:N ratio at 14th day corresponded to TSP $>$ RP $>$ PHA $>$ Control, respectively. More decrease in $\mathrm{C}: \mathrm{N}$ ratio was witnessed past day 28 till the end of the trial but the outcomes of enhanced P-nutrient sources were not meaningfully altered apart from $\mathrm{CaCl}_{2}$-treated vermicompost. Final C:N ratios were in the range of 10-12 in vermicompost treated with $\mathrm{P}$-nutrient source fertilizer, whereas control and $\mathrm{CaCl}_{2}$-treated vermicompost had $\mathrm{C}: \mathrm{N}$ ratios of 14 and 22, respectively (Fig. 3). Thus, the addition of P-nutrient bearing source aided reduction of vermicompost $\mathrm{C}: \mathrm{N}$ ratio and in turn enhanced cow dung-waste paper mixtures vermidegradation at the early stages of vermicomposting up to day 28 , beyond which treatment effect was minimal. However, vermicompost treated with $\mathrm{CaCl}_{2}$ declined minimally but not lower than 22 at day 56 (Fig. 3). Bernal et al. (2009) stated that the drop in C:N ratio might be credited to the breakdown of carbon-based substance because of bacteriological action as well as ammonification and nitrification; both bacteriologically facilitated methods are most powerful all through this period.

\section{Effects of $P$ and $C a$ sources on inorganic nitrogen dynamics}

Table 1 reveals significant treatment $\times$ time interaction on ammonium N. A linear increase in ammonium was observed from day zero to day 28 and sharply declined thereafter till termination of the experiment at day 56 (Fig. 4a). The highest increase of about $179 \mathrm{mg} / \mathrm{kg}$ ammonium-N was observed in waste mixtures mixed with TSP, whilst the
Fig. 4 Effects of $\mathrm{P}$ and $\mathrm{Ca}$ sources on inorganic nitrogen dynamics

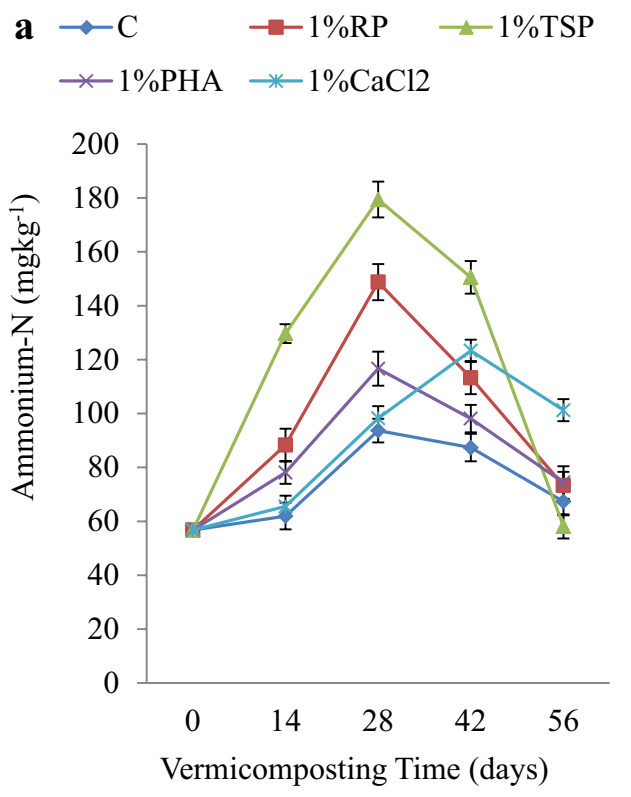

b
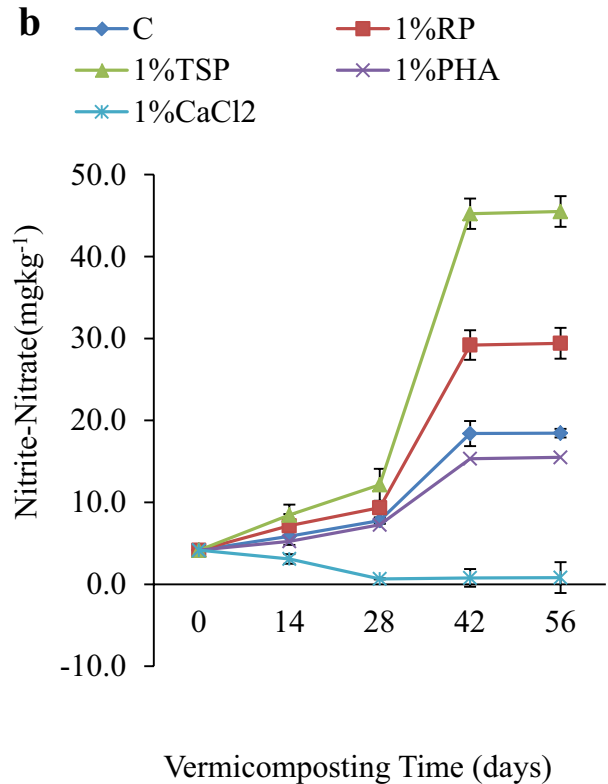
control samples had the least value of $\mathrm{NH}_{4}{ }^{+}-\mathrm{N}(93 \mathrm{mg} /$ $\mathrm{kg}$ ). Other treatments increased and followed the order of $\mathrm{RP}>\mathrm{Control}>\mathrm{PHA}>\mathrm{CaCl}_{2}$.

At day $56, \mathrm{CaCl}_{2}$-treated vermicompost had the best $\mathrm{NH}_{4}{ }^{+}-\mathrm{N}$ content, recommending that vermicomposting procedure was lowest and that $\mathrm{Ca}$ had no basic part in the decomposition of the waste mixtures. High $\mathrm{NH}_{4}{ }^{+}-\mathrm{N}$ concentration at the beginning could be due to $\mathrm{N}$-mineralization, showing the dynamic of OM change and the incidence of unstable medium (Bernal et al. 1998; Zucconi and de Bertoldi 1987). However, many researchers have reported that $\mathrm{NH}_{4}{ }^{+}-\mathrm{N}$ concentration during vermicomposting usually decreased to reach stability level in final analysis (Mupondi et al. 2010; Levanon and Pluda 2002). Bernal et al. (1998) reported that reductions of $\mathrm{NH}_{4}{ }^{+}-\mathrm{N}$ concentration prompted increments of $\mathrm{NO}_{3}{ }^{-}-\mathrm{N}$ through nitrification, when temperatures turned out to be more satisfactory.

Nitrate-nitrite in the vermicompost followed the same linearly increasing pattern up to day 14 with higher increment observed where TSP was included, while the lowest nitrate-N substance were recorded with compost treated with $\mathrm{CaCl}_{2}$ till 28 days (Fig. 4b). A sharp increment was noticed from day 28 till day 42 in all the treatments except from mixtures blended with $\mathrm{CaCl}_{2}$. But, at day 56, TSP, RP, Control and PHA treatments increased linearly with TSP having the highest nitrate concentration of $(49 \mathrm{mg} /$ $\mathrm{kg}$ ), RP (30 mg/kg), Control (20 mg/kg) and PHA (13 mg/ $\mathrm{kg}$ ), respectively. Although Bernal et al. 1998 reported a noteworthy decrease in $\mathrm{NO}_{3}{ }^{-}-\mathrm{N}$ when wood shavings were added to vermicompost and attributed it to increased TOC/ TN which favoured microbial immobilization, nevertheless,
Fig. 5 Effect of $\mathrm{P}$ and $\mathrm{Ca}$ source on the humification parameter

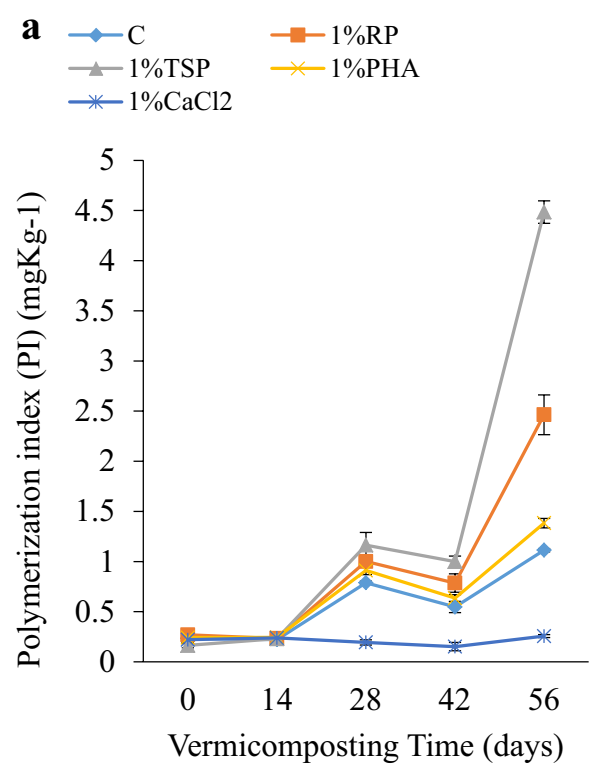

$\mathbf{b}$
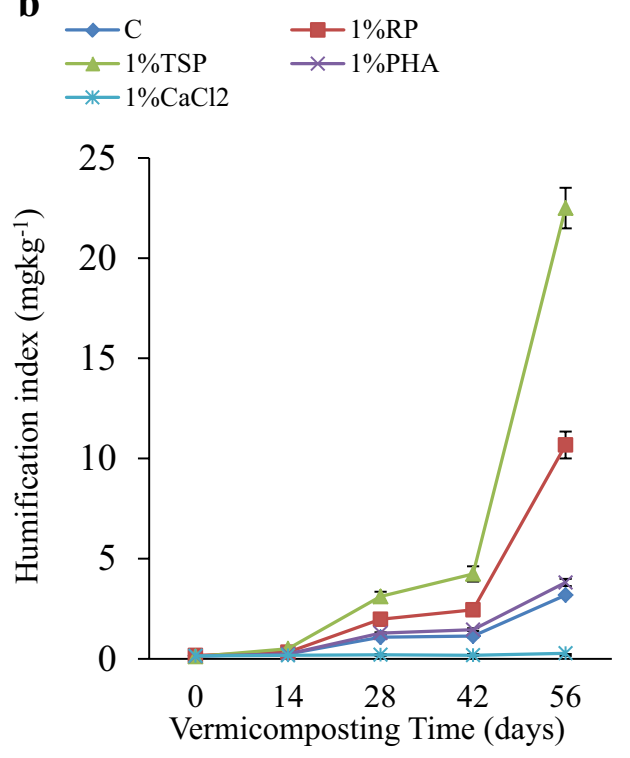

$\multimap \mathrm{C} \rightarrow-1 \% \mathrm{RP} \rightarrow 1 \% \mathrm{TSP}$

$\leftarrow 1 \% \mathrm{PHA} \quad *-1 \% \mathrm{CaCl} 2$

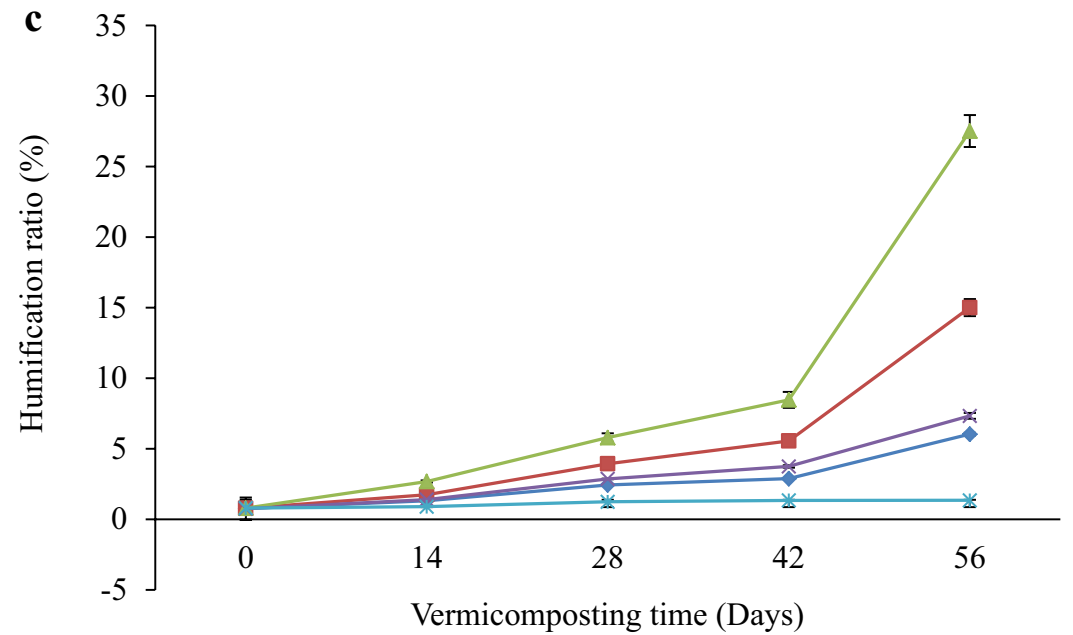


Table 3 Relationship between different P-fertilizer source and Bray P extractable during vermicomposting of cow dung-waste paper mixtures mixed with rock phosphate

\begin{tabular}{|c|c|c|c|c|c|c|}
\hline $\begin{array}{l}\text { P-fertilizer } \\
\text { source }(\%)\end{array}$ & Regression equation & $R^{2}$ & $\begin{array}{l}\text { Rate of Bray } 1 \mathrm{P} \\
\text { release }(\mathrm{mgP} / \mathrm{kg} / \\
\text { day) }\end{array}$ & $\begin{array}{l}\text { Predicted Bray } 1 \mathrm{P} \\
\text { at } 56 \text { days }(\mathrm{mg} / \mathrm{kg})\end{array}$ & $\begin{array}{l}\text { Observed Bray } 1 \mathrm{P} \\
\text { at } 56 \text { days }(\mathrm{mg} / \mathrm{kg})\end{array}$ & $\begin{array}{l}\text { Net Bray } 1 \mathrm{P} \text { increase } \\
\text { from day } 1(\mathrm{mg} / \mathrm{kg})\end{array}$ \\
\hline Control & $Y=-0.3277 X^{2}+25.213 X+75.061$ & 0.8855 & $6.7 \mathrm{~d}$ & 172.7 & 173 & 93 \\
\hline $\mathrm{RP}$ & $Y=-0.1342 X^{2}+11.678 X+40.883$ & 0.5226 & $11.7 \mathrm{c}$ & 208.3 & 208.3 & 128.3 \\
\hline TSP & $Y=-0.1123 X^{2}+10.089 X+42.893$ & 0.4802 & $24.7 \mathrm{a}$ & 424.8 & 425 & 345 \\
\hline PHA & $Y=-0.0645 X^{2}+6.6401 X+52.538$ & 0.4644 & $14.0 \mathrm{~b}$ & 192.2 & 192.2 & 112.2 \\
\hline $\mathrm{CaCl}_{2}$ & $Y=0.033 X^{2}-2.615 X+74.653$ & 0.8743 & $2.0 \mathrm{e}$ & 28.1 & 28.1 & -51.9 \\
\hline $\mathrm{CV}(\%)$ & & & 5 & 5 & 5 & \\
\hline$p$ value & & & $<0.001$ & $<0.001$ & $<0.001$ & \\
\hline
\end{tabular}

Numbers followed by different letters in each column are significantly different according to $p \leq 0.05$

the increase in $\mathrm{N}$ was not immediate and could be as a result of the decline in desiccated mass of OM in the medium because of the breakdown by earthworms as also reported by (Gomez-Brandon et al. 2008). Another reason behind this augmentation could be the closeness and activity of worms in the substrate and discharge of chemicals as reported by (Mupondi et al. 2010).

\section{Effects of $P$ and Ca source on extractable Bray $P$}

Addition of treatments into waste mixtures had significant effect on the amount of $\mathrm{P}$ discharge. However, it differed significantly between treatments $\times$ time relationship (ANOVAR) during the study period (Fig. 5). The highest initial extractable Bray P $(713 \mathrm{mg} / \mathrm{kg})$ corresponded to the TSPtreated waste mixtures and the lowest to $\mathrm{CaCl}_{2}$-treated waste mixtures (Table 3). In all the treatments, the release of $\mathrm{P}$ by each applied treatments (TSP, RP, PHA and control) either increased or decreased with time and at some points remained linear. At day 14, PHA-treated samples had the highest increment $(464 \mathrm{mg} / \mathrm{kg}$ ) in extractable Bray P compared with TSP-treated waste $(328 \mathrm{mg} / \mathrm{kg})$. In case of RP and Control, they followed similar pattern from the beginning till 56th day, while $\mathrm{CaCl}_{2}$-treated vermicompost remained the lowest up to termination of the experiment (Table 3).

This increase is due to the utilization and mineralization of phosphorus by microbes and enzymes living in the earthworm's gut (Suthar and Singh 2008), as well as OM mineralization in the substrate. Likewise, (Jadia and Fulekar 2008) stated a rise in nitrogen and phosphorus level and a decrease in C/N ratio. But (Parvaresh et al. 2004) observed a decrease in $\mathrm{P}$ and ascribed it to inorganic $\mathrm{P}$ assimilation freed from the earthworms' tissues, variation of the process, feature of ingredients eaten by earthworms and the conditions of the experiment.

According to (Bhattacharya and Chattopadhyay 2002), phosphate bacteria enable the dissolution of $\mathrm{P}$ from P-bearing minerals through the production of phosphatase enzymes. Discharge of $\mathrm{P}$ is facilitated via phosphate chemicals provided through microorganisms living in earthworm's gut and cast (Yan et al. 2012).

\section{Effect of $P$ and Ca source on the humification parameter}

Humification parameters [polymerization index (PI), HI, and HR] of waste mixtures were affected by all treatments during vermicomposting period. These effects were similar to the trend observed in C:N ratio as shown in (Table 1). At the beginning of vermicomposting up to 14 days, all treated waste materials had the same PI of $0.2 \mathrm{mg} / \mathrm{kg}$ (Fig. 5a). However, as vermicomposting progressed (28 days), changes in PI were noticed. Waste mixtures that received TSP had the highest significant $(p<0.05)$ increase, whereas waste mixtures to which $\mathrm{Cacl}_{2}$ was added had the least PI of 0.3. Substantial changes in PI were observed at day 56: waste mixtures mixed with TSP had highest PI value of 4.5 followed by RP (2.5), while control and PHA had equal PI value of 1.2 , respectively, but $\mathrm{CaCl}_{2}$ had 0.1 separately. Similarly, humification indexes (HI) from day zero to day 14 of vermicomposting were not different when compared with the control (Fig. 5b). However, from day 28 to day 56, waste mixed with TSP had the highest HI values of (4.5 and $22 \mathrm{mg} / \mathrm{kg}$, respectively), whilst the least HI was recorded in cow dung-waste paper mixed with $\mathrm{CaCl}_{2}$ and in the control. The added P-nutrient sources followed the same trend for humification ratio (HR) in vermicompost from the beginning to the end of the study period (Fig. 5c).

The ratio $C_{\mathrm{HA}} / C_{\mathrm{FA}}$, also known as "degree of polymerization or polymerization index," increases during the composting process, reflecting the formation of complex molecules $\left(C_{\mathrm{HA}}\right)$ from simpler one $\left(C_{\mathrm{FA}}\right)$ and the occurrence of synthesis of organic compounds resistant to microbial degradation (Plaza et al. 2008). Roletto et al. (1985) used the ratio of $C_{\mathrm{HA}} / C_{\mathrm{FA}}$ to establish the humification level of the OM of compost from different origins, including manure, indicating 
Table 4 Effect of treatments on the phytotoxicity of cow dungwaste paper vermicompost

\begin{tabular}{|c|c|c|c|c|c|c|c|c|c|}
\hline \multirow[t]{2}{*}{ Treatment } & \multicolumn{3}{|l|}{ Tomato } & \multicolumn{3}{|l|}{ Carrot } & \multicolumn{3}{|l|}{ Radish } \\
\hline & RRE (\%) & RSG (\%) & GI (\%) & RRE (\%) & RSG (\%) & GI (\%) & $\operatorname{RRE}(\%)$ & RSG (\%) & GI (\%) \\
\hline $\mathrm{C}$ & $80.0 \mathrm{c}$ & $113.4 \mathrm{c}$ & $89.5 \mathrm{~d}$ & $90.8 \mathrm{ab}$ & $108.3 \mathrm{c}$ & $97.4 \mathrm{c}$ & $95.6 \mathrm{~b}$ & $91.7 \mathrm{c}$ & $87.4 \mathrm{c}$ \\
\hline RP & $77.1 \mathrm{~d}$ & $133.4 \mathrm{~b}$ & $108.8 \mathrm{c}$ & $99.3 \mathrm{ab}$ & $108.3 \mathrm{c}$ & $120.6 \mathrm{~b}$ & $91.2 \mathrm{~b}$ & $91.7 \mathrm{c}$ & $95.6 b$ \\
\hline TSP & $125.7 \mathrm{a}$ & $143.4 \mathrm{a}$ & $155.6 \mathrm{a}$ & $109.3 \mathrm{a}$ & $133.4 \mathrm{a}$ & $129.9 \mathrm{a}$ & $102.1 \mathrm{a}$ & $108.4 \mathrm{a}$ & $103.2 \mathrm{a}$ \\
\hline PHA & $111.6 \mathrm{~b}$ & $106.7 \mathrm{~d}$ & $115.7 b$ & $93.4 \mathrm{ab}$ & $125.0 \mathrm{~b}$ & $115.2 \mathrm{~b}$ & $85.7 \mathrm{c}$ & $104.2 \mathrm{~b}$ & $91.2 \mathrm{c}$ \\
\hline $\mathrm{CaCl}_{2}$ & $75.8 \mathrm{~d}$ & $90.0 \mathrm{e}$ & $69.6 \mathrm{e}$ & $84.8 \mathrm{~b}$ & $91.7 \mathrm{~d}$ & $75.8 \mathrm{~d}$ & $77.7 d$ & $75.0 \mathrm{~d}$ & $60.1 d$ \\
\hline CV (\%) & 8 & 6 & 7 & 6 & 5 & 4 & 7 & 7 & 7 \\
\hline$p$ value & $<0.001$ & $<0.001$ & $<0.001$ & $<0.001$ & $<0.001$ & $<0.001$ & $<0.001$ & $<0.001$ & $<0.001$ \\
\hline
\end{tabular}

Numbers followed by different letters in each column are significantly different according to the LSD test at $p \leq 0.05$. Relative root elongation (RRE), relative seed germination (RSG) and Germination index (GI) a value greater than 1 for a good humification degree. However, (Senesi 1989 and Iglesias-Jimenez and Perez-Garcia 1992) have suggested that a ratio $C_{\mathrm{HA}} / C_{\mathrm{FA}}$ greater than 1.6 indicates a good maturity degree achieved by the organic matter. The ratio $\left(C_{\mathrm{HA}} / C_{\mathrm{FA}}\right)$ slightly decreases during the vermicomposting time, reaching a value of 1.5 , suggesting a roughly reduction in the contents of molecules with a high degree of condensation and humification, which could indicate that the earthworm activities led to a homogeny degradation of all types of $\mathrm{C}$ compounds without selectivity, however, maturity level reached do not decrease.

\section{Effect of $P$ and Ca sources on the phytotoxicity}

None of the extracts from the final vermicomposted products treated with $\mathrm{P}$ or Ca sources had any constrain on seed sprouting of test crops (Table 4). In tomato, each treatment increased the RSG except where PHA and $\mathrm{CaCl}_{2}$ were added. The highest percent of RSG was found with vermicompost mixed with TSP. The same statistically significant $(p<0.0001)$ trend of RSG was observed for radish and carrot except where $\mathrm{CaCl}_{2}$ was added. Tomato had the main important value of $125.7 \%$ for RRE trailed by radish $109 \%$, whereas the least percent of $102 \%$ was observed with carrot upon addition of TSP (Table 4). All tested crops had GI of more than $80 \%$ on vermicomposts treated with $\mathrm{P}$ but less than $80 \%$ where $\mathrm{CaCl}_{2}$ was applied. This can be because of well advance of decay of natural substrates and diminishment of phytotoxic mixes coming about because of vermicompost maturing. All extracts used for seed germination test were freed of phytotoxicity except were $\mathrm{CaCl}_{2}$ extract was used because of high $\mathrm{EC}$ in regard of Ca-treated product and resilience of tested seeds to salinity (Tiquia 2010). Our results correspond to (Paradelo et al. 2008) who said that GI between 50 and $80 \%$ mean moderate phytotoxicity. Likewise, the more than $80 \%$ GI watched for all tested seeds in this examination showed that addition of P as TSP, PHA and RP with $E$. fetida produced fertilizer product freed of phytotoxins as reported by Zucconi et al. (1981 and Tam and Tiquia (1998). Bustamante et al. (2001) also linked GI of $\geq 80 \%$ to the absence of phytotoxins in composts. Of the three P sources tested, water-soluble P vermicomposts had the highest germination indices for all crops tested indicating the superiority of these vermicomposts.

\section{Morphology of vermicompost revealed by scanning electron microscopy}

(Figure 6c-f) confirmed the degree of humification of the resultant vermicompost from SEM results. At the beginning of the experiment, the waste mixture had a compressed group both of roughage and protein fibres morphologically (Fig. 6a) which were disintegrated by the activities of microbes in enzyme's gut after 56 days (Fig. 6b). However, where earthworms and TSP, RP, PHA were added, highly degraded, fine grain texture vermicompost was produced from the grinding nature exhibited by the earthworm (Fig. 6a-f) except for $\mathrm{CaCl}_{2}$-treated vermicompost (Fig. 6f). The level of grinding activities of the waste materials by earthworms became more intensified with treatments. Vermicompost produced from TSP (readily available $\mathrm{P}$ ) enrichment had well-humified and high aggregate particles which was evident in the humification parameters, showing the importance of $\mathrm{P}$ rather than $\mathrm{Ca}\left(\mathrm{CaCl}_{2}\right)$ during bioconversion of waste. Additional affirmation of intense mixtures decomposition is also revealed from SEM pictures (Fig. 6a, c), which indicated that RP addition escalated the vermidegradation of mixtures, and that addition of $1 \% \mathrm{P}$ of RP brought about reliably more prominent waste conversion during vermicomposting period with the other RP treatments. The resultant SEM photo of the vermicompost exhibited a specific physical appearance that portrayed a scattered separated minute in nature contrast to the control. Thus, SEM images in this study were similar to that of (Lim et al. 2015, 2016), and it reveals that increase in the decomposition of the mixtures significantly depends on time. The wider contrasts in the degree of decomposition observed from various treatments at 14th and 28th days agreed with the time of most extreme microbial action (Unuofin et al. 2016). 


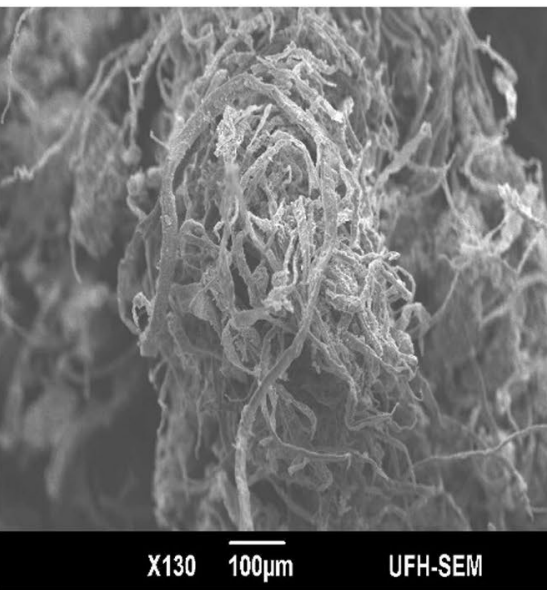

a control at (0Day)

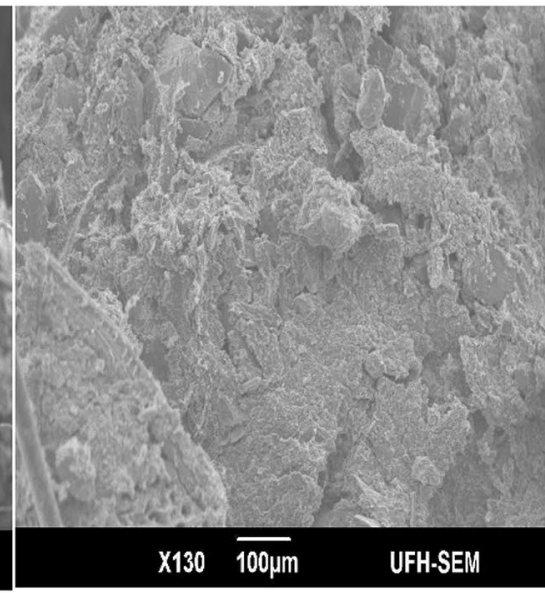

b Control at (56days)

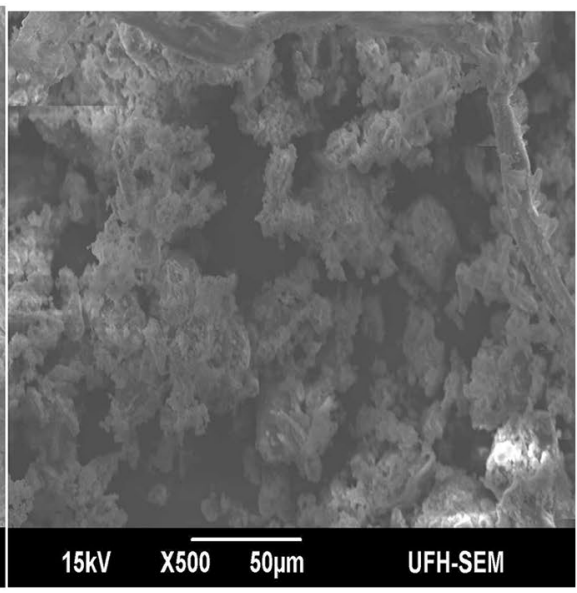

c RP treated vermicompost (56days)
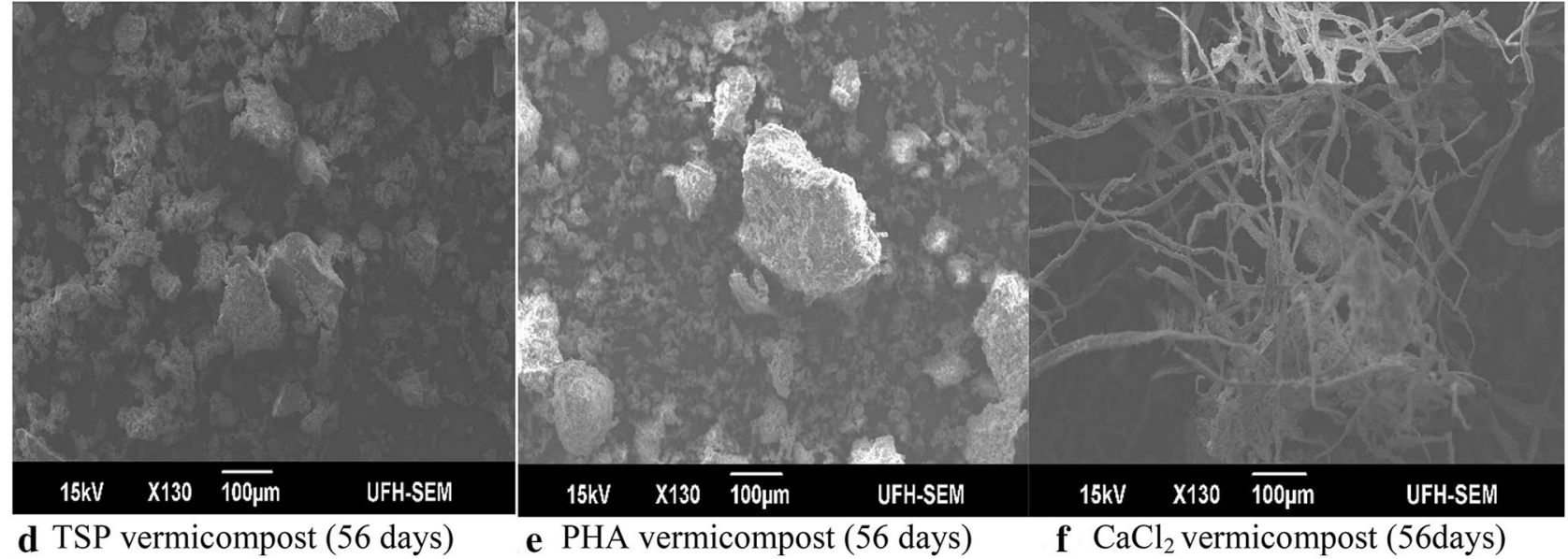

d TSP vermicompost (56 days)

e PHA vermicompost (56 days)

f $\mathrm{CaCl}_{2}$ vermicompost (56days)

Fig. 6 Scanning electron microscope pictures showing P and Ca source effects on vermicompost morphological properties

\section{Conclusion}

The results of this study have demonstrated that phosphorous and not calcium is responsible for the enhanced biodegradation of waste mixtures mixed with $\mathrm{P}$ bearing like rock phosphate during vermicomposting. However, the use of watersoluble $\mathrm{P}$ sources to enhance vermicomposting may not be justifiable where impure and less expensive $P$ sources such as rock phosphates are available as their use can result in equally mature and P-enriched vermicomposts in 6-8 weeks. The effectiveness of added $\mathrm{P}$ in enhancing vermicomposting appears linked to its ability to stimulate microbial growth, $\mathrm{C}: \mathrm{N}$ ratio decrease, rise in PI, HI and HR. However, it could also be partially linked to meeting the $P$ nutritional requirements of the earthworms. This latter effect will need to be explored in future studies.

Acknowledgements Funding was provided by the directorate of Research and Innovation Centre of Walter Susulu University.

\section{Compliance with ethical standards}

Conflict of interest The authors indicated that there is no conflict of interest.

Open Access This article is distributed under the terms of the Creative Commons Attribution 4.0 International License (http://creativeco mmons.org/licenses/by/4.0/), which permits unrestricted use, distribution, and reproduction in any medium, provided you give appropriate credit to the original author(s) and the source, provide a link to the Creative Commons license, and indicate if changes were made.

\section{References}

Anderson JM, Ingram JSI (1996) Tropical soil biology and fertility: a handbook of methods, 2nd edn. CAB International, Wallingford

Atiyeh RM, Edwards CA, Subler S, Metzger JD (2000) Earthworm processed organic waste as components of horticultural potting media for growing marigold and vegetable seedlings. Compt Sci Utility 8:215-223. https://doi.org/10.1080/1065657x.2000.10701994

Bernal MP, Paredes C, Sanchez-Monedero MA, Cegarra J (1998) Maturity and stability parameters of composts prepared with a 
wide range of organic wastes. Bioresour Technol 63:91-99. https ://doi.org/10.1016/S0960-8524(97)00084-9

Bernal MP, Alburquerque JA, Moral R (2009) Composting of animal manures and chemical criteria for compost maturity assessment: a review. Bioresour Technol 100:5444-5453. https://doi. org/10.1016/j.biortech.2008.11.027

Bhattacharya S, Chattopadhyay GN (2002) Increasing bioavailability of phosphorus from fly ash through vermicomposting. J Environ Qual. 31:2116-2119. https://doi.org/10.2134/jeq2002.2116

Biswas DR, Narayanasamy G (2006) Rock phosphate enriched compost, an approach to improve low-grade Indian rock phosphate. Bioresour Technol 97:2243-2251. https://doi.org/10.1016/j.biort ech.2006.02.004

Bustamante MA, Restrepo A, Moral R, Paredes C, Pérez-Murcia MD, Alburquerque JA, Bernal MP (2001) Recycling of digestates from biogas production composting. J Environ Sci Health. 36:415-436

Del Carmen Vargas-García M, Francisca Suárez-Estrella F, José López M, Joaquín M (2006) Influence of microbial inoculation and cocomposting material on the evolution of humic-like substances during composting of horticultural waste. Process Biochem 41:1438-1443. https://doi.org/10.1016/j.procbio.2006.01.011

Edwards CA, Walker RB, Maskell P, Watson CA, Rees RM, Stockdale EA, Knox OGG (2010) Improving bioavailability of phosphate rock for organic farming, genetic engineering, bio-fertilization. Soil Qual Organic Farming 4:99-117

Fares F, Albalkhi A, Dec J, Bruns MA, Bollag JM (2005) Physicochemical characteristics of animal and municipal wastes decomposed in arid soils. J Environ Qual 34(4):1392-1403

Garg VK, Kaushik P (2005) Vermistabilization of textile mill sludge spiked with poultry droppings by an epigeic earthworm Eisenia fetida. Bioresour Technol 96:1063-1071. https://doi. org/10.1016/j.biortech.2004.09.003

Garg P, Gupta A, Satya S (2006) Vermicomposting of different types of waste using Eiseniafoetida: a comparative study. Bioresour Technol 97:391-395. https://doi.org/10.1016/j.biortech.2005.03.009

Gomez-Brandon M, Lazcanoa C, Domíngueza J (2008) The evaluation of stability and maturity during the composting of cattle manure. Chemosphere 70:436-444. https://doi.org/10.1016/j.chemospher e.2007.06.065

Gupta R, Mutiyar PK, Rawat NK, Saini MS, Garg VK (2007) Development of a water hyacinth based vermireactor using an epigeic earthworm Eisenia fetida. Bioresour Technol 98:2605-2610. https ://doi.org/10.1016/j.biortech.2006.09.007

Haimi J, Huhta V (1987) Comparison of composts produced from identical wastes by vermistabilization and conventional composting. Pedobiologia 30(2):137-144

Hait S, Tare V (2011) Vermistabilization of primary sewage sludge. Bioresour Technol 102:2812-2820. https://doi.org/10.1016/j.biort ech.2010.10.031

Iglesias-Jimenez E, Perez-Garcia V (1992) Determination of maturity indices for city refuses composts. Agric Ecosyst. Environ. 38:331-343. https://doi.org/10.1016/0167-8809(92)90154-4

Jadia CD, Fulekar MH (2008) Vermicoposting of vegetable waste: a bio-physiochemical process based on hydro-operating bioreactor. Afr J Biotechnol 7(20):3723-3730

Kaushik P, Garg VK (2004) Dynamics of biological and chemical parameters during vermicomposting of solid textile mill sludge mixed with cow dung and agricultural residue. Bioresour Technol 94(203-209):15158514. https://doi.org/10.1016/j.biort ech.2003.10.033

Khwairakpam M, Bhargava R (2009) Bioconversion of filter mud using vermicomposting employing two exotic and one local earthworm species. Bioresour Technol 100:5846-5852. https:// doi.org/10.1016/j.biortech.2009.06.038

Kumar V, Narula N (1999) Solubilization of inorganic phosphates and growth emergence of wheat as affected by
Azotobacter chroococcum. Biol Fertil Soils 28:301-305. https:// doi.org/10.1007/s003740050497

LECO Corporation (2003) Truspec CN carbon/nitrogen determinator instructions manual. LECO Corporation, St Joseph

Levanon D, Pluda D (2002) Chemical, physical and biological criteria for maturity in composts for organic farming. Compost Sci Util. 10:339-346. https://doi.org/10.1080/1065657X.2002.10702096

Lim SL, Wu TY, Lim PN, Shak KPY (2015) The use of vermicompost in organic farming: overview, effects on soil and economics. J Sci Food Agric 95(6):1143-1156. https://doi.org/10.1002/jsfa.6849

Lim SL, Lee LH, Wu TY (2016) Sustainability of using composting and vermicomposting technologies for organic solid waste biotransformation: recent overview, greenhouse gases emissions and economic analysis. J Clean Prod. 111:262-278. https://doi. org/10.1016/j.jclepro.2015.08.08

Loh TC, Lee YC, Liang JB, Tan D (2005) Vermicomposting of cattle and goat manures by Eisenia foetida and their growth and reproduction performance. Bioresour Technol 96(1):111-114. https:// doi.org/10.1016/j.biortech.2003.03.001

Masciandaro G, Ceccanti B, Garcia C (1997) Soil agro-ecological management, fertirrigation and vermicompost treatments. Bioresour Technol 59:199-206. https://doi.org/10.1016/S0960 -8524(96)00142-3

Mishra MM (1992) Enrichment of organic manures with fertilizers. In: Tandon HLS (ed) Nontraditional sector for fertilizer use. FDCO, New Delhi, pp 48-60

Mupondi LT (2010) Improving sanitization and fertiliser value of dairy manure and waste paper mixtures enriched with rock phosphate through combined thermophilic composting and vermicomposting. A PhD Thesis. pp 25-40

Mupondi LT, Mnkeni PNS, Muchaonyerwa P (2010) Effectiveness of combined thermophilic composting and vermicomposting on biodegradation and sanitization of mixtures of dairy manure and waste paper. Afr J Biotechnol 9:4754-4763

Ndegwa PM, Thompson SA, Das KC (2000) Effects of stocking density and feeding rate on vermicomposting of biosolids. Bioresour Technol 71(1):5-12

Paradelo R, Moldes AB, Rodríguez MT (2008) Relationship between heavy metals and phytotoxicity in composts. Cienc Tecnol Aliment. 6(2):143-151. https://doi.org/10.1080/11358120809487639

Parvaresh A, Movahediyanatar H, Hamidiyan L (2004) Chemical quality and value vermicompost fertilizer made from sewage sludge. J Water Wastewater 15(50):29-33

Plaza C, Nogales R, Senesi N, Benitez E, Polo A (2008) Organic matter humification by vermicomposting of cattle manure alone and mixed with two-phase olive pomace. Bioresour Technol 99:50855089. https://doi.org/10.1016/j.biortech.2007.09.079

Premono EDM, Moawad MA, Vlek PLG (1996) Effect of phosphatesolubilizing Pseudomonas putida on the growth of maize and its survival in the rhizosphere. Indones J Crop Sci 11:13-23

Reinecke AJ, Venter JM (1987) Moisture preferences, growth and reproduction of the Compost worm Eisenia fetida (Oligochaeta). Biol Fertil Soils 3:135-141. https://doi.org/10.1007/bf00260595

Roletto E, Barberis R, Consignlid M, Jodice R (1985) Chemical parameters for evaluation of compost maturity. Biocycle 26(2):46-47

Senesi N (1989) Composted materials as organic fertilizer. Sci Total Environ 81:521-542. https://doi.org/10.1016/00489697(89)90161-7

Senesi N, Plaza C, Brunetti G, Polo A (1992) A comparative survey of recent results on humic-like fraction in organic amendments and effects on native soil humic substances. Soil Biol Biochem 39:1244-1262. https://doi.org/10.1016/0048-9697(92)90079-8

Singh CP, Amberger A (1990) Humic substances in straw compost with rock phosphate. Biol Wastes. 31(3):165-174. https://doi. org/10.1016/0269-7483(90)90156-M 
Singh J, Kalamdhad AS (2013a) Effect of Eisenia fetida on speciation of heavy metals during vermicomposting of water hyacinth. Ecol Eng 60:214-223. https://doi.org/10.1016/j.ecoleng.2013.07.010

Singh J, Kalamdhad AS (2013b) Reduction of bioavailability and leachability of heavy metals during vermicomposting of water hyacinth. Environ Sci Pollut Res 20:8974-8985. https://doi. org/10.3184/095422914X14043211756226

Singh J, Kaur A, Vig AP, Rup PJ (2009) Role of Eisenia fetida in rapid recycling of nutrients from bio sludge of beverage industry. Ecotoxicol Environ Saf 73:430-435. https://doi.org/10.1016/j.ecoen v.2009.08.019

Suthar S, Singh S (2008) Vermicomposting of domestic waste by using two epigeic earthworms (Perionyx excavatus and Perionyx sansibaricus). Int J Environ Sci Techol 5(1):99-106

Tam NFY, Tiquia SM (1998) Elimination of phytotoxicity during cocomposting of spent pig-manure sawdust litter and pig sludge. Bioresour Technol 65:43-49. https://doi.org/10.1016/S0960 $-8524(98) 00024-8$

Tiquia SM (2010) Reduction of compost phytotoxicity during the process of decomposition. Chemosphere 79(5):506-512. https://doi. org/10.1016/j.chemosphere.2010.02.040

Tripathi G, Bhardwaj P (2004) Comparative studies on biomass production, life cycles and composting efficiency of Eisenia fetida (Savigny) and Lampito mauritii (Kinberg). Bioresour Technol 92(3):275-283. https://doi.org/10.1016/j.biortech.2003.09.005

Unuofin FO, Mnkeni PNS (2014) Optimization of Eisenia fetida stocking density for the bioconversion of rock phosphate enriched cow dung waste paper mixtures. Waste Manag. https://doi. org/10.1016/j.wasman.2014.05.018

Unuofin FO, Siswana M, Cishe EN (2016) Enhancing rock phosphate integration rate for fast bio-transformation of cow-dung wastepaper mixtures to organic fertilizer. Springer Plus 6:7. https://doi. org/10.1186/s40064-016-3497-2

Walkley A, Black IA (1934) An examination of the degtareff method for determining soil organic matter, and a proposed modification of the chromic acid titration method. Soil Sci 34:29-38. https:// doi.org/10.1097/00010694-193401000-00003

Yan YW, Nor Azwady AA, Zulkifli HS, Muskhazli M, Suraini AA, Teng SK (2012) Ehancement of plant nutrient contents in rice straw vermicompost through the addition of rock phosphate. Acta Biol Malays 1(1):41-45. https://doi.org/10.7593/abm/1.1.41

Zucconi F, de Bertoldi M (1987) Compost specifications for the production and characterization of compost from municipal solid waste. In: de Bertoldi M, Ferranti MP, L'Hermite P, Zucconi F (eds) Compost: prod, quality and use. Elsevier, Essex, pp 30-50 (Elsevier applied science)

Zucconi F, Forte M, Monaco A, De Bartoldi M (1981) Biological evaluation of compost maturity. Biocycle 22:27-29

Publisher's Note Springer Nature remains neutral with regard to jurisdictional claims in published maps and institutional affiliations. 